Article

\title{
Adoption and Dissemination Pathways for Climate-Smart Agriculture Technologies and Practices for Climate-Resilient Livelihoods in Lushoto, Northeast Tanzania
}

\author{
Mary Nyasimi ${ }^{1}{ }^{*}$, Philip Kimeli ${ }^{1}$, George Sayula ${ }^{2}$, Maren Radeny ${ }^{1}$, James Kinyangi ${ }^{3}$ \\ and Catherine Mungai ${ }^{1}$ \\ 1 CGIAR Research Program on Climate Change Agriculture and Food Security, P.O. Box 30709-00100 Nairobi, \\ Kenya; p.kimeli@cgiar.org (P.K.); m.radeny@cgiar.org (M.R.); c.mungai@cgiar.org (C.M.) \\ 2 Selian Agricultural Research Institute; P.O. Box 6024 Arusha, Tanzania; gsayula@hotmail.com \\ 3 African Development Bank, Avenue Joseph Anoma, 01 BP 1387 Abidjan 01, Cote d'Ivoire; \\ j.kinyangi@afdb.org \\ * Correspondence: m.nyasimi@cgiar.org
}

Academic Editors: Bruce A. McCarl and Jianhong E. Mu

Received: 19 June 2017; Accepted: 26 July 2017; Published: 15 August 2017

\begin{abstract}
Smallholder farmers in East Africa need information and knowledge on appropriate climate-smart agriculture (CSA) practices, technologies, and institutional innovations in order to effectively adapt to changing climatic conditions and cope with climate variability. This paper assesses farmer adoption of climate-smart agricultural practices and innovation after being exposed to Farms of the Future Approach (FotF). First; we explore and assess the various CSA technologies and practices; including institutional innovations farmers are adopting. Second; we identify and document farmer learning and dissemination pathways that can enhance adoption of CSA technologies and practices. Third; we identify existing institutions that enhance adoption of CSA practices. We use household survey data, complemented by qualitative information from focus group discussions and key informant interviews. The results show farmers are adopting a variety of CSA technologies, practices, and institutional innovations to after participating in the FotF approach with use of improved crop varieties, agroforestry, and scientific weather forecast information cited as the main practices. To minimize their risks and reduce vulnerabilities, farmers are diversifying and integrating five to 10 CSA practices in one season. Matengo pits, SACCOs, and efficient energy stoves were adopted by very few farmers due to their high initial investment costs and unsuitability to the area. Ninety-eight percent of farmers reported that they receive agricultural information orally from a variety of sources including government extension workers, seed companies, researchers, traditional experts, neighbors, radio agricultural shows, religious groups, farmer groups, and family members. Lastly, farmers reported that the FotF approach is a useful tool that enabled them to interact with other farmers and learn new CSA practices and innovations. Suggested improvements to make on the FotF included include longer trip duration, increased number of farmer participants, and gender balance and age considerations to include youth.
\end{abstract}

Keywords: gender; adoption; dissemination pathways; analogue tools; Farms of the Future; CSA; Tanzania

\section{Introduction}

Projected and observed impacts of climate change on agriculture, food security, and poverty are raising global concerns. In East Africa, small-scale agricultural production is already under pressure. 
Small-scale farmers in the region face numerous challenges, including increasingly constrained access to land, decreased land area, and a decline in soil fertility, leading to low crop yields and poor market access [1-3]. A growing population places further demands on food, leading to increasing food insecurity and poverty levels [4,5]. Rural communities in East Africa mainly depend on rain-fed small-scale agriculture for their livelihood, although it is extremely vulnerable to changes in climate and climate variability. Changes in rainfall patterns and temperatures are altering the functioning of agricultural landscapes in overwhelming and often destructive ways. East African farmers are, therefore, compelled to adapt their agricultural practices to those that can build their adaptive capacity and enhance climate resilience. Adaptive capacity is defined as the capacity of a community to reconfigure itself in the face of climate change without substantial decreases in function [6]. It is closely associated with the ability to learn, innovate, and cooperate in order to maximize group learning and shared benefits. Climate resilience is the ability for an environment and people to handle, recover from, and thrive in the face of climatic disturbances or shocks. Climate resilience in the context of rural agricultural-dependent communities is comprised of ecological resilience, social resilience, and economic resilience [7].

The IPCC report [8,9] project, with high confidence, an increase in rainfall, with some seasons experiencing intensive droughts. These changes in rainfall patterns, temperature, and other extreme weather events are projected to increase crop failures, pest and disease outbreaks, and degradation of land and water resources in East Africa [8,9]. These impacts are likely to hit rural communities hard because of their high dependence on rain-fed agriculture, coupled with low adaptive capacity [10]. Increasing climate uncertainties are also likely to lead to risk-averse behavior among farmers, forcing them to depend on low-input and low-risk agricultural technologies. Small-scale subsistence farmers have been identified as the most vulnerable to climate change in East Africa. Their vulnerabilities make the effects of climate change to be far-reaching with potential negative effects on future generations. For these farmers to adapt to climate variability, while at the same time preparing for the future climatic changes, they must improve their adaptive capacities in terms of knowledge and skills.

In order to adapt to changing climate conditions and other challenges, farmers in East Africa have been making changes to their agricultural practices. The changes in agricultural practices are targeting both crop and livestock production and include use of new crop varieties and animal breeds, soil and land management practices, water conservation technologies, and improved fodder production [11]. These technologies and practices are expected to boost adaptive capacity, food security, and contribute to climate change mitigation in resource-poor smallholder farming systems of East Africa, referred to as climate-smart agriculture (CSA) technologies. FAO defines CSA as agriculture that sustainably increases productivity, resilience (adaptation), reduces/removes GHGs (mitigation), and enhances achievement of national food security and development goals [12]. CSA encompasses a set of practices that are suitable to local climatic, socioeconomic, and cultural conditions.

In Lushoto, located in northern Tanzania, households are already adapting to changing climatic conditions [13]. While the results from this research do not conclusively link adaptation strategies to climate change, it was cited as a key driving factor. The magnitude of behavioral change, however, appears to be limited to farming practices that are fairly easy to undertake without major disruptions to the farming system or substantial changes to land, labor, or water allocation.

With the farming systems in East Africa already facing unparalleled pressures from different factors, new learning processes, knowledge, and tools are desperately needed. In particular, increasing climate variability coupled with dire predictions further reinforces the need for farmer training and knowledge to enable them build their adaptive capacity.

\subsection{Climate Analogues and Farms of the Future Approach}

In order to prepare for changing climatic conditions and strengthen their adaptive capacity, farmers need to understand what their future climate is likely to be. According to [14], 30 percent of the world's climates are expected to be completely novel under climate change, thus 70 percent 
of expected future climates already exist somewhere else on the globe. The spatial and temporal variability in climate can be used of understanding what the future holds for a particular site. Farmers can start preparing for their future climate by learning from what their future climate is likely to be. The Consultative Group for International Agricultural Research (CGIAR) Research Program on Climate Change, Agriculture and Food Security (CCAFS) has developed a climate-analogue tool that can be used to connect sites with statistically similar climates (analogous) across space and/or time (see [15] for a detailed description of the tool).

The Farms of the Future (FotF) approach uses the CCAFS climate-analogue tool to connect farmers to their possible future climates through farmer-to-farmer exchanges between spatial analogue sites. Spatial analogues refer to areas whose climate today appears to be similar to the future projected climate of another location. Linking farmers to areas experiencing their plausible future climate can facilitate knowledge sharing and learning, and provide opportunities for transferring technologies and innovations that can improve farmers' adaptive capacities.

Since smallholder farmers are already experiencing the impacts of climate change, it is expected that adoption and diffusion of climate-resilient agricultural technologies will be brisk. However, several studies have documented that adoption and subsequent diffusion (the process of communicating a new technology through various dissemination ways) of agricultural technologies is complex due to a number of reasons including uncertainty, cost and benefits of the technology, gender, social capital, socio-cultural practices, high costs of labor, access to markets, and credit among others [16-18]. Other studies have shown that learning through farm visits, farmer-to farmer interactions, and informal social networks greatly influence a farmers' decision to adopt new agricultural technologies [19]. Thus, the relationship between farmers will determine when and how information will be disseminated and whether the technology will be adopted. For example, farmer-to-farmer information sharing is more effective in persuading an individual to accept a new practice due to their close and daily interactions, while mass media such as radio and television are an efficient way to create awareness of agricultural technology $[20,21]$. The FotF approach is structured in such a way that it is supposed to trigger farmers to learn, share, and adopt new climate-resilient agricultural practices and technologies. This is because farmers who participate in the FotF learn new technologies from farmers who are already experiencing their future climate. Additionally, farmers who participate in the FotF learning experience are supposed to be instrumental in communicating and disseminating the CSA practices that they have learned.

The first pilot of the FotF approach in East Africa was carried out in 2012 in Lushoto, Tanzania by a team from the Natural Resources Institute-University of Greenwich, in collaboration with CCAFS, Tanzania's Selian Agricultural Research Institute (SARI), and the African Highlands Initiative [22], Lushoto is located in the Northern Tanzania highlands and is one of six CCAFS sites in East Africa (Figure 1). The CCAFS climate-analogue tool was used to identify plausible alternative future climate (spatial analogue) sites for Lushoto—-sites with a current climate similar to the projected future climate of Lushoto.

Fifteen farmers from two villages (Yamba and Mbuzii), including both men and women, and five key agricultural innovation systems (AIS) stakeholders from Lushoto took part in a 10-day learning journey to several sites including Morogoro, Mufindi, Njombe, and Mbinga in the Southern Highlands (see Figure 2). AIS stakeholders are partners with a vested interest in addressing a common problem and identifying solutions that are technically feasible, socio-culturally, and economically acceptable [23-26]. The farmers were selected based on a criteria developed by the community that included gender balance, different ages, farmers involved in CCAFS activities, and who had been interviewed during the CCAFS baseline survey [27]. The AIS actors were drawn from different economic sectors including tourism, agricultural input dealers, community development organizations, and the agricultural and livestock sectors. 


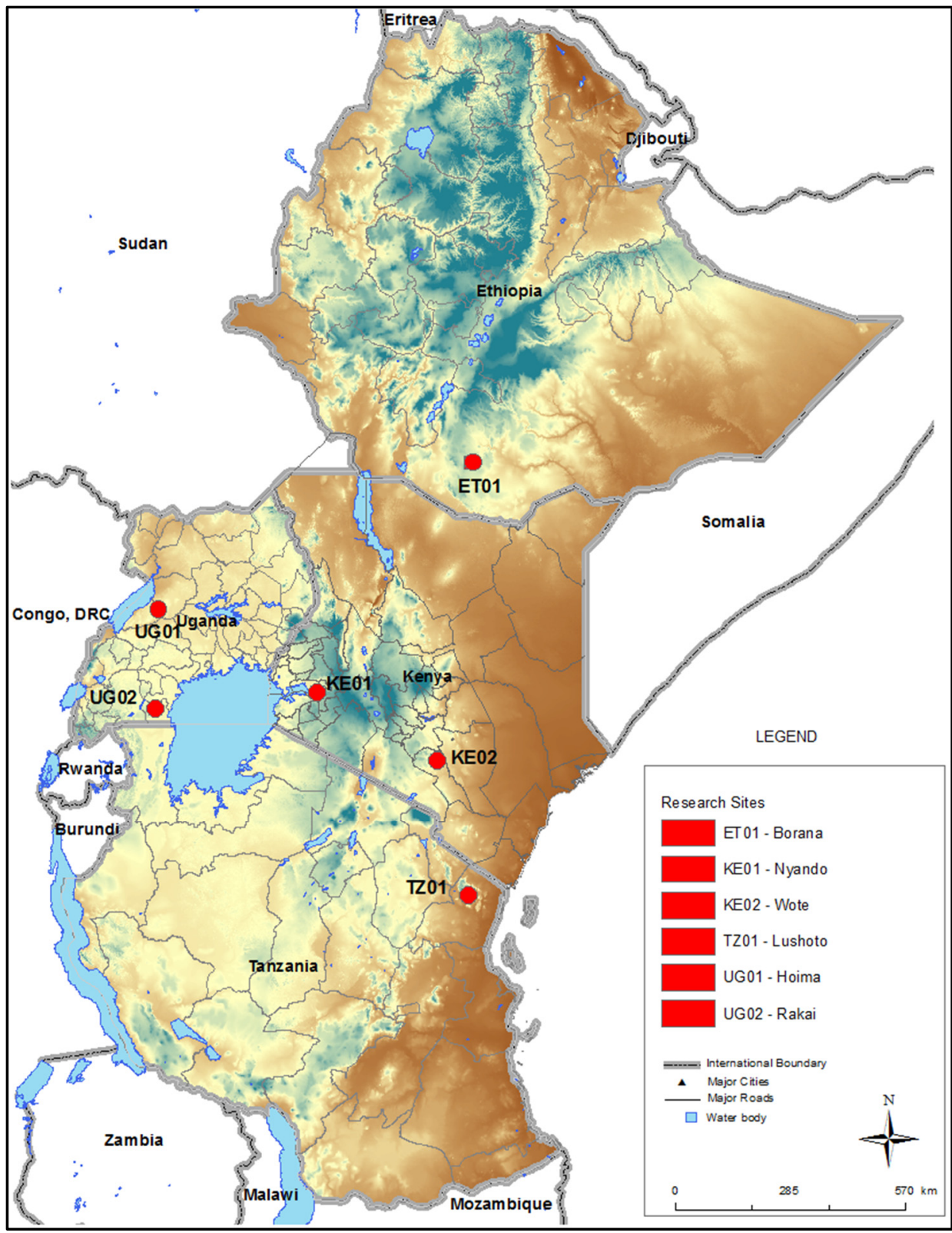

Figure 1. Location of study site.

During the learning journey, farmers and the AIS stakeholders were exposed to various CSA technologies and institutional innovations for adaptation and risk management with five major stops (Figure 2). The CSA technologies that farmers were exposed to included crop breeding, soil and water management, tree and coffee nurseries, fish rearing, bee-keeping, and growing of avocado, banana and maize. The institutional innovations included markets, value chains, input supply systems, savings and credit cooperatives (SACCOs), energy production and conservation (biogas, improved stoves, tree nursery), and community weather stations Some of the farmers were trained in amateur filming and photographic skills and were provided with handheld flip cameras to document the learning process to enable sharing of their learning experiences with other farmers within their communities who did not participate in the learning journey. 


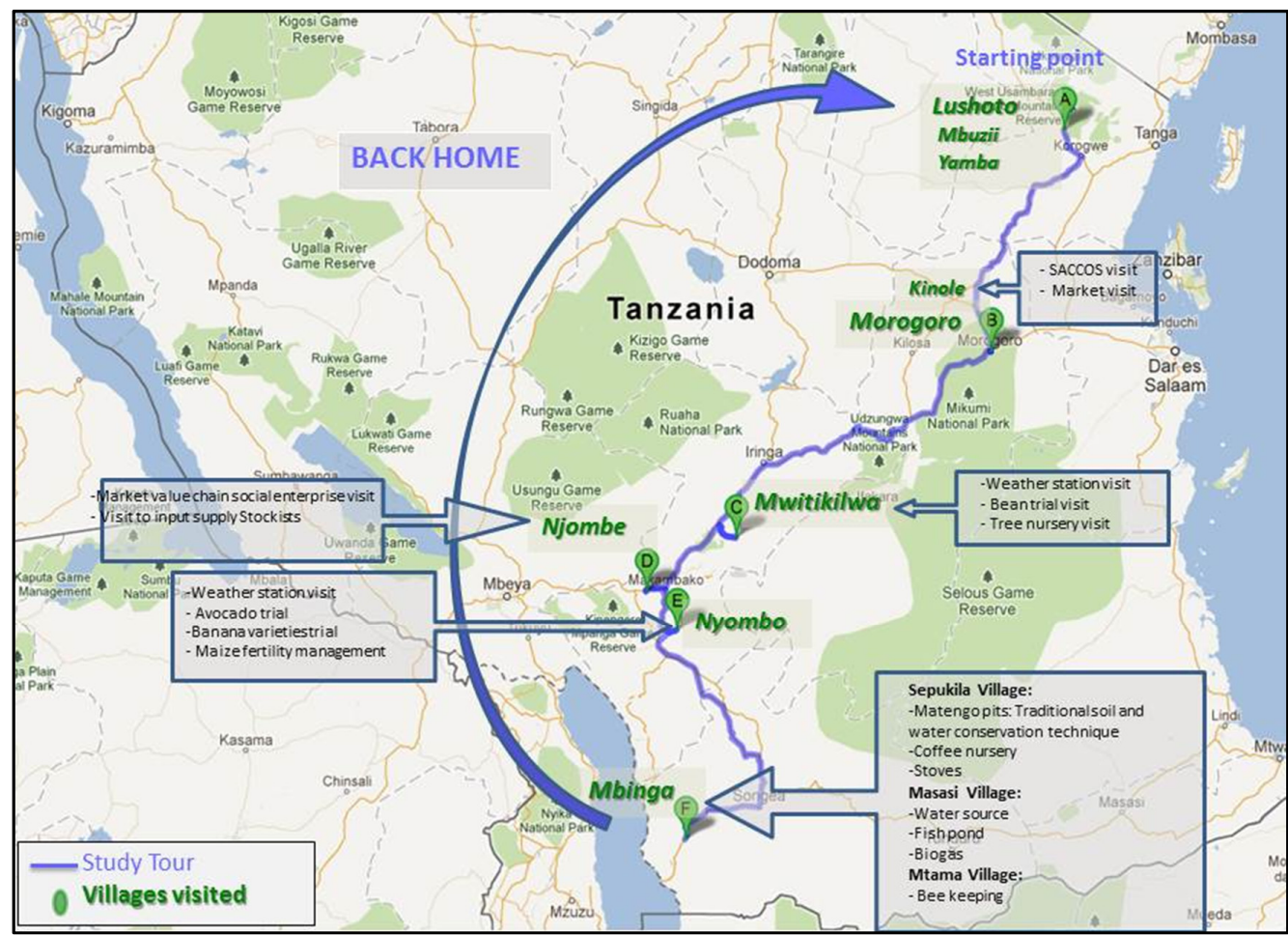

Figure 2. Map of Tanzania showing the different places that the farmers visited during the exchange visit.

\subsection{Objectives}

Effective climate change adaptation requires appropriate technological and institutional innovations, including an enabling policy environment that can reduce the farmer's vulnerability to climate-related risks by creating economic opportunities that build livelihoods and increase resilience [28]. An effective adaptation strategy needs to adequately address physical and biological impacts of climate change, as well as local people's norms, values, and tolerance of conditions and risk [29]. At the heart of climate change adaptation is farmers' access to information about appropriate innovations that provide resilience in the face of climate variability and change. Indeed, creating an environment and opportunities where farmers can learn from other farmers who are currently experiencing their plausible future climatic conditions can increase their future adaptive capacity.

The learning journey exposed farmers and the AIS stakeholders from Lushoto to their plausible future climate and the potential technological and institutional ways of adapting to these changes. This study is a follow-up of the FotF pilot in Tanzania and examines the effectiveness of the FotF approach as a mechanism for enhancing adaptation learning and identifies promising information dissemination pathways. First, we explore and assess the various CSA technologies and institutional innovations farmers have adopted after the learning journey. Second, we identify and document farmer learning and dissemination pathways that can enhance adoption of CSA technologies and practices. Third, we identify existing institutions that enhance adoption of CSA practices. The paper addresses three specific research questions:

- What CSA practices are farmers adopting after the learning journey?

- What factors hinder farmers from adopting CSA technologies and practices?

- What dissemination pathways are farmers using to share information on CSA? 


\section{Methodology}

As discussed in Section 1.2, this study was conducted in last quarter of 2015 in Lushoto in Tanzania (Figure 1). Lushoto is one of the six CCAFS sites in East Africa where researchers, local partners, and farmers are working together to evaluate a portfolio of CSA interventions. The aim of these strategic partnerships is to improve farmers' income and resilience to climatic risks and boost their ability to adapt to climate change.

Lushoto is part of the Usambara Mountains and is a global hotspot for biodiversity. With its excellent climatic conditions, Lushoto attracts not only farming communities but also tourists. Lushoto is characterized by two agro-climatic zones-humid warm and humid cold zones. The annual rainfall pattern is bimodal, ranging from 1200 to $1300 \mathrm{~mm}$ per year. However, these amounts have been decreasing over time, as indicated in Figure 3 [30,31]. The wet seasons are March-May and October-December each year. The mean annual temperature is $16{ }^{\circ} \mathrm{C}$, with a humidity of $70 \%[30,31]$. Lushoto's landscape is highly heterogeneous, with diverse micro eco-zones within a relatively small area and characterized by very hilly slopes with wide valley bottoms.

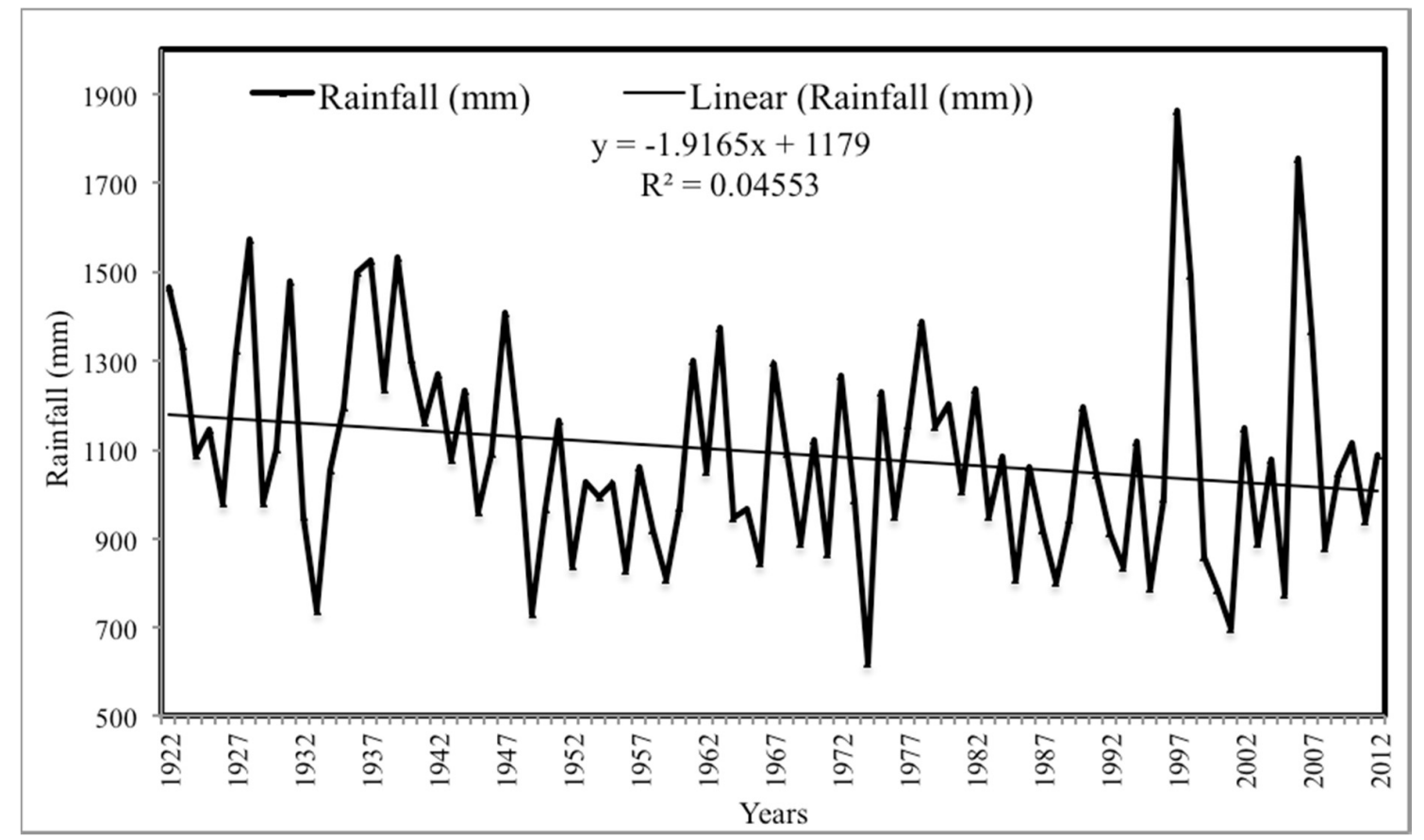

Figure 3. Lushoto long-term annual rainfall trend (1922-2012).

Lushoto is among the most densely populated rural districts in Tanzania, with an average property size of about two acres per household. The majority of farmers in Lushoto depend on subsistence crop production for their livelihood, including fruits and vegetables. The higher elevation areas are characterized by mixed crop and livestock, and intensive farming systems, while the lower elevation areas are characterized by agro-pastoral farming systems that are intensively cropped with a variety of vegetables throughout the year. Soil erosion is a huge challenge mainly due to the steep terrain, deforestation, and high population pressure.

This paper uses quantitative data from household surveys, complemented with qualitative information from community-level focus group discussions (FGDs) from four villages and key informant interviews. A mixed-methods approach (quantitative and qualitative) addresses the complexity of understanding farmers' perceptions and ensures the study was comprehensive in both breadth and depth [32-34]. The use of both qualitative and quantitative methods led to cross-checking multiple data sources to increase trust in the validity of the study conclusions [35]. Of the four 
villages, two were those where some of farmers participated in the FotF learning journey (Yamba and Mbuzii) while the other two, Gare and Kwang'wenda, are adjacent/neighboring to the villages that participated in the learning journey. We hypothesize that farmers who participated in the learning journey were more likely to start sharing their learning experiences with farmers within their villages and neighboring villages (i.e., people they are familiar with). The targeted sample size per village was 20 households, totaling 80 households from the four target villages, including the 15 households who participated in the learning journey from the two villages, and taking into account gender balance. However, this was a voluntary study and households that did not participate in the FotF could pull out at any point. Therefore, we increased the sample size to 22 households per village and, as predicted, seven households pulled out mid-way, leaving the study with a total sample of 81 households. The household survey collected information on household characteristics, types of CSA practices and their benefits, CSA practices that farmers learned on the FotF trip, who is using and not using and why, and sources and types of information on CSA. All 15 farmers and AIS stakeholders who participated in the FotF journey were interviewed using both closed and open-ended questions. The open-ended questions enabled the farmers to express their views when they felt that they had not satisfactorily responded in the closed ended questions, thus allowing the researcher to discover and note new responses that farmers gave instinctively.

Information on farmers' perception on the FotF as a learning tool was collected through FGDs. Planning for the FGDs was done through the village elders who informed the selected participants from the list of CCAFS baseline. Three FGDs were conducted with three different groups of farmers: 15 participants of mixed gender for the farmers who took part in the learning trip and separate groups for men and women who did not participate in the learning trip. FGDs averaged 20 farmers. Information collected from the FGDs included lessons learnt, challenges, what CSA practices and institutional innovations the farmers have started implementing after the learning journey, how farmers shared what they learnt with other farmers, and whether farmers adopted what was shared, including modifications on the CSA practices. Questions used in the FGDs were tailored for the FotF and the non-FotF farmers. This is because the FotF participants were to share what they experiences were before, during and after the climate journey. The non-FotF farmers responded to questions on their experiences from what they had learned from FotF farmers.

During FGDs, we incorporated cobweb network mapping to enable farmers to visualize the different sources of information on CSA practices and technologies. In each FGD, farmers listed all the sources of information and ranked them according to their importance. The ranking ranged from one to five, with one being the least important source of information and five the most important information source. The cobweb mapping exercise, which is easy to draw and visualize, enabled farmers to discuss and agree amongst themselves on the value of a particular source of information after which they adjusted accordingly.

\section{Results and Discussion}

\subsection{Characteristics of the Study Population}

Over 80 percent of the households interviewed were male-headed, with an average household size of 4.8 people (Table 1). The dependency ratio is about 0.4 , suggesting that most of the population in Lushoto falls within the working group. Most of the households had at least one member who had attained primary education (i.e., at least seven years of schooling in Tanzania). Slightly more than one-quarter of the households had members who had completed secondary school education, with very few households having members who had completed tertiary education. 
Table 1. Household characteristics.

\begin{tabular}{|c|c|}
\hline Demographic Characteristics & Percent of Households $(n=81)$ \\
\hline \multicolumn{2}{|l|}{ Sex of respondent (\%) } \\
\hline Male & 66.7 \\
\hline Female & 33.3 \\
\hline \multicolumn{2}{|l|}{ Household type (\%) } \\
\hline Male headed & 82.7 \\
\hline Female headed & 17.3 \\
\hline \multicolumn{2}{|c|}{ Highest level of formal education of any household member (\%) } \\
\hline None & 4.9 \\
\hline Primary (eight years of elementary education) & 61.7 \\
\hline Secondary (our years of high school) & 27.2 \\
\hline Tertiary (post-high school training) & 6.2 \\
\hline \multicolumn{2}{|l|}{ Average household size } \\
\hline Number of persons in a household & 4.8 \\
\hline Number of young dependents ( $<5$ years) & 0.59 \\
\hline Number of people of working age (5-60 years) & 3.7 \\
\hline Number of old dependents ( $>60$ years) & 0.54 \\
\hline Dependency ratio ${ }^{1}$ & 0.31 \\
\hline
\end{tabular}

\subsection{Uptake of CSA Technologies and Practices}

The 15 farmers and AIS stakeholders who took part in the 10-day learning journey were exposed to various CSA technologies, practices, and institutional innovations (Figure 2):

- Soil and water conservation practices: Use of Matengo pits (a traditional soil and water conservation technique), irrigation and terracing, early planting, intercropping, and minimum tillage;

- Forestry innovations and environmental conservation strategies: Establishment and management of a tree nursery, fruit trees, agroforestry trees, construction of terraces that are reinforced with drought tolerant fodder grasses strips, coffee seedling nurseries and biodigesters;

- Cropping innovations and livelihood diversification: Intensive cropping of cloves, black pepper, potato trials, avocado, and coffee varieties, a coffee nursery and bee-keeping;

- Improving access to finance through collective action: Establishment of a savings and credit (SACCOS) group, a scheme that has enabled farmers to pool resources and bargain for better prices;

- Weather information services: A community managed weather station, where farmers collect climate data, which is then shared with the Tanzania Meteorological Agency (TMA). This community managed weather station raised the farmers' consciousness of the changing climate and the importance of integrating indigenous knowledge and scientific weather forecasts as well as develop strategies to support TMA to gather climate data from the local level.

Consideration of the above practices is based on the three pillars of CSA that seeks to address demand for increasing agricultural productivity and incomes, building social-ecological resilience of livelihood systems to climate change, while minimizing agriculture's contribution to greenhouse gas emissions [36,37] (see Table 2 for the benefits of these practices). 
Table 2. Benefits that farmers observe after using various CSA technologies, practices, and institutional innovations (for detailed description see [38]).

\begin{tabular}{|c|c|}
\hline CSA Practice & Benefits \\
\hline Matengo pits & $\begin{array}{l}\text { Promotes an integrated soil, water and nutrient management by retaining water and the use of } \\
\text { crop residues to support the pits leads to improved and sustained soil fertility and crop } \\
\text { productivity, reduced soil erosion, and enhanced soil carbon sequestration. }\end{array}$ \\
\hline Irrigation & $\begin{array}{l}\text { Small-scale irrigation offer key opportunities for adaptation as water supplies dwindle and } \\
\text { rainfall becomes more erratic. Through irrigation, farmers can diversify into high value vegetable } \\
\text { production thus reducing risks of crops loss and increasing incomes. }\end{array}$ \\
\hline Terracing & $\begin{array}{l}\text { Promotes soil and water conservation, especially on steep slopes to reduce soil erosion and } \\
\text { increased water percolation. The terraces are reinforced with grass strips and agroforestry trees } \\
\text { (for timber and fruits), thus contributing to mitigation and increased incomes. }\end{array}$ \\
\hline $\begin{array}{l}\text { Traditional and scientific } \\
\text { weather forecasts }\end{array}$ & $\begin{array}{l}\text { Reduces risks associated with failed seasons or variable rainfall and enable farmers to make better } \\
\text { farming decisions for improved productivity and risk management. }\end{array}$ \\
\hline Agroforestry & $\begin{array}{l}\text { Establishment of deep root, drought tolerant leguminous trees that fix nitrogen and shade leaves } \\
\text { during the rainy season, providing organic residues and nutrients. Contributes to carbon } \\
\text { sequestration, reduced soil erosion and moisture stress, and tree products that are sold for income. }\end{array}$ \\
\hline $\begin{array}{l}\text { Biogas and use of efficient } \\
\text { stoves }\end{array}$ & $\begin{array}{l}\text { Reduces greenhouse gas emission by utilizing methane from cow dung to generate energy for } \\
\text { household consumption. Replaces purchase of kerosene and harvesting of trees, thus saving } \\
\text { families income. Bioslurry is used as manure, hence increasing soil fertility. Efficient stoves are } \\
\text { combustion and fuel-efficient and reduce particulate air pollution, cooking time and time spent } \\
\text { acquiring firewood. }\end{array}$ \\
\hline Composting & $\begin{array}{l}\text { Composting of crop residues and organic domestic wastes is used for soil fertility and improve } \\
\text { crop productivity. Also contributes to improved soil structure, moisture retention and reduced } \\
\text { emissions from application of raw animal manure. }\end{array}$ \\
\hline Crop rotation & $\begin{array}{l}\text { A crop diversifying practice that is used to achieve crop diversity, reduce incidences of pest and } \\
\text { diseases of particular crop, improves soil structure and soil fertility through nitrogen fixing crops } \\
\text { and reduces soil erosion. }\end{array}$ \\
\hline $\begin{array}{l}\text { Drought and diseases } \\
\text { tolerant crop varieties }\end{array}$ & $\begin{array}{l}\text { Adaptive crop varieties that are stress tolerance and disease resistance; early maturing to avoid } \\
\text { crop loss from shorter growing seasons or unreliable rains. This leads to improved productivity } \\
\text { and reduced risk of crop failure }\end{array}$ \\
\hline $\begin{array}{l}\text { Drought tolerant and } \\
\text { deeper rooted fodder } \\
\text { grasses and/or legumes }\end{array}$ & $\begin{array}{l}\text { Contributes towards food security and increased livestock productivity. Use of improved fodders } \\
\text { leads to reduction of emissions from enteric fermentation of livestock through improved digestion. } \\
\text { Increased milk production and heavier anima weight leads to more income. }\end{array}$ \\
\hline $\begin{array}{l}\text { Early planting and use of } \\
\text { early maturing crop } \\
\text { varieties }\end{array}$ & $\begin{array}{l}\text { Varieties that are more adapted to low and unreliable rains, and shortened growing seasons thus } \\
\text { leading to reduced risk of crop failures. }\end{array}$ \\
\hline Minimal tillage & $\begin{array}{l}\text { Conserves soil moisture and control erosion through minimum soil disturbances. It improves crop } \\
\text { productivity and reduces soil compaction thus reducing emission }\end{array}$ \\
\hline Intercropping & $\begin{array}{l}\text { Intercrop of legume and non-legume crop and trees contributes to nitrogen fixation, improved } \\
\text { water retention, reduced crop failures to drought, pest and diseases. Leaves of trees intercrop are } \\
\text { used as mulch and compost, thus contributing to above ground carbon sequestration. }\end{array}$ \\
\hline SACCOs & $\begin{array}{l}\text { Offers safety nets to give farmers through stronger marketing power. SACCO offers access to } \\
\text { credit to farmers to start CSA practices such as irrigation and purchase of food during droughts. }\end{array}$ \\
\hline $\begin{array}{l}\text { Management of a tree } \\
\text { nursery and tree planting }\end{array}$ & $\begin{array}{l}\text { Trees nursery provide income. The planted trees increase soil fertility and can help control erosion, } \\
\text { as well as provide fuel wood and timber, medicines and fruits. Trees can also store substantial } \\
\text { amounts of carbon. }\end{array}$ \\
\hline Livelihood diversification & $\begin{array}{l}\text { Diversification of crops, livestock (bee-keeping), trees and irrigation is potential response to } \\
\text { overcoming unreliable rainfall and drought. This will minimize weather-induced losses and } \\
\text { stabilize incomes. }\end{array}$ \\
\hline
\end{tabular}

Several factors influence farmers' ability to adopt CSA practices. Among the key factors include (a) availability and access to resources needed to use the practices such as land, labor, and financial capital; (b) potential benefits to be accrued vis-à-vis other practices; (c) whether they have the required skills and information to use it; (d) ability to cope with challenges that might arise during or after using the practices; and (e) compatibility with local social and cultural practices [39,40]. For farmers in Lushoto, the ability to adopt CSA practices is influenced by the above factors, albeit for different technologies and practices. Table 3 summarizes the uptake of the CSA technologies and institutional innovations by the farmers who took part in the learning journey (FotF farmers) and those who did not participate (non-FotF farmers). Improved crop varieties, agroforestry, and scientific weather forecast information were the main CSA practices farmers were using, with similar patterns of uptake for FotF 
and non-FotF farmers. Few farmers adopted the use of Matengo pits, SACCOs, efficient energy stoves, with no significant differences between the FotF farmers and non-FotF farmers.

Table 3. Uptake of CSA practices and innovations farmers were exposed to during the learning journey.

\begin{tabular}{cccc}
\hline CSA Practices and Innovations & $\begin{array}{c}\text { Percent of FotF Farmers } \\
(\boldsymbol{n}=\mathbf{1 5})\end{array}$ & $\begin{array}{c}\text { Percent of Non-FotF } \\
\text { Farmers }(\boldsymbol{n}=\mathbf{6 6})\end{array}$ & $\begin{array}{c}\text { Overall \% Using the } \\
\text { CSA }(\boldsymbol{n}=\mathbf{8 1})\end{array}$ \\
\hline Improved crop varieties & 100.0 & 93.9 & 95.1 \\
Agroforestry & 93.3 & 83.3 & 85.2 \\
Scientific weather forecasting & 73.3 & 66.7 & 67.9 \\
Efficient stoves & 26.7 & 27.3 & 27.2 \\
Matengo pits & 13.3 & 4.6 & 6.2 \\
SACCOs & 6.7 & 3.0 & 3.7 \\
Biogas, biodigester & 6.7 & 0.00 & 1.2 \\
\hline
\end{tabular}

After learning about scientific weather forecasts during the learning journey, most farmers in Lushoto now appreciate, and increasingly use, both indigenous knowledge and scientific weather forecasts from TMA to plan their farming activities in a particular season, thus making better farming decisions. Before the learning journey, most farmers mainly used indigenous knowledge weather forecasting information provided by traditional forecasters [41]. The combination of scientific and traditional knowledge ensures that farmers are informed on the likely date of onset of rain, the duration and amount of rain to expect, the types and variety of crops to grow, and types of inorganic and organic fertilizer to use and when to apply them. The weather information is packaged and disseminated through flyers posted on community boards, shared through the church, and handed out at community meetings.

According to one of the women farmers who participated in the learning journey:

Adapting to climate change is both a science and an art. It involves and requires engagement of several practices, science, actions and magic ... that is unique and probably unrepeatable elsewhere ... whatever I do to ensure that I have enough food for my family involve two things, that is, farming and acquiring weather decisions such as when to prepare the land and sow seeds, what to plant that are made and implemented by me ... FotF participant, 2014.

The low rates of uptake for the biogas digester can be attributed to high initial capital investments. Savings and credit cooperatives (SACCOs) are an institutional innovation that also had very low uptake. In Tanzania, SACCOs have been known to improve the investment climate by providing opportunities for rural people to secure returns on their savings and access to loans at affordable interest rates [42,43] and can, therefore, contribute to risk management. SACCOs are also a form of collective action that can help farmers, especially women, increase farm productivity and access to credits and markets, share knowledge, information and productive assets, provide greater bargaining power in sourcing for farm inputs, and better prices for their produce and empowerment [44]. This is more so for women who in the absence of men, get opportunities to participate in decision-making and take on leadership roles [44-46]. Despite its low rate of uptake in Lushoto, SACCOs can improve the welfare of its members by providing an alternative way for farmers to save their earnings and access loans at more affordable interest rates.

According to a female farmer:

Low crop yields due to unpredictable rains prior to the start of the growing season, diseases and pests all affect the quantity and quality of produce we get. By joining a SACCO, at least, we will pull our produce together and be able to market as a whole, thus reducing exploitation by middle men/women. We also get to pool our resource together and we can get loans that can enable us purchase seeds that can withstand less rainfall.

High membership fees (approximately Tanzania Shillings 10,000 or USD 6) and lack of understanding of the importance of SACCOs among farmers were reported as the major limiting 
factors. Therefore, there is need for information and awareness among farmers on the importance of collective action, including savings groups that can enable them to cope during seasons of low rainfall that leads to low agricultural productivity.

One farmer (2014) noted that:

We need to start saving for the future of our children because our rainfall patterns are changing and our children might not rely solely on farming to survive. We need to start building assets that do not rely on rainfall. Investment in non-farming activities can provide our children with a soft cushion to land on during lean periods. Through SACCOs, we can start saving little amounts each week or month. But the membership fee is rather high especially for women households that do not have husbands. Maybe such women can be supported by financial organizations and given loans to start non-farming activities.

Other farmers concurred that through their SACCO, they have been able to improve their price bargaining power especially for farmers who are growing vegetables on the valley bottoms. The SACCO is enabling the members to have a collective voice and access ago-advisory information especially during their meetings.

According to the chairperson of the SACCO that has 19 members:

Our SACCO is relatively new and we are muddling through the process to ensure that it is functional. But we have greater incentive to make it work because all the members know each other, their interests in agriculture, and we can adapt the SACCO to reflect our members changing needs and circumstances. Our focus is to improve our member's livelihoods as the climate is changing.

Other CSA practices farmers were exposed to, such as bee-keeping, fish farming in ponds, and agricultural value addition enterprises that can generate income, have not been taken up by farmers in Lushoto. For example, FotF participants learned about food processing, however, none of them have started a food processing enterprise. Farmers cited lack of knowledge on value addition enterprises, bee-keeping and fish farming, implying the need for follow-up training and support to farmers through the extension systems.

According to a woman farmer:

I needed more information on some of the technologies that we learned during the journey to facilitate me and other farmers to start it on our farms. We didn't spend sufficient time on the journey to learn in-depth about the technologies and hence most farmers are reluctant to take the risk. For instance, I do not know where to get beehives and unfortunately I have not contacted the District Agricultural officer.

Farmers who were not using scientific weather information cited unreliability and inaccessibility of weather information as the main reason. Women particularly reported a lack of adequate weather information to plan for their farming activities. Moreover, weather information is usually passed on to the women through their husbands or village chiefs, and, in most cases, they do not know how to use the information. While there are multiple initiatives in East Africa that are aimed at producing and delivering climate information services for farmers [47,48], many challenges still remain in terms of accurate and timely weather and climate forecasts to support farmers efforts to adapt to a changing climate and increasing climate risks.

A young woman reported that:

"I have heard that we will have less rainfall this year. But what does that mean? What crops should I plant when we have less rain? That is a difficult question to answer because the information provided is not enough to assist me to plan what crops to grow, when, what fertilizer to use, what livestock should I save since I might not have enough water for the animals".

During FGDs interactions, farmers expressed the importance of integrating traditional and scientific weather forecasting and packaging it in a user friendly way. To be effective for 
farmers, the weather forecast information (indigenous and scientific forecasts) should be timely and complimented with agro-advisories such as crop suitability, cultivar selection, planting date, planting density, weeding, water management, pests and diseases, and fertilizing [49].

After learning about Matengo pits, some farmers tried the technology on their farms and found it unsuitable for their environment. Matengo pits are labor intensive to establish and not suitable for the soil type and topography of Lushoto. The major soil types in Lushoto are Humic and Chromic Acrisols, Luvisols and Lixisols for most of the mountainous hilly areas, while the valley bottoms have Fluvisols and some pockets of Gleysols [50,51]. Bench terracing was also labor intensive and dangerous because of the steep slopes in Lushoto. For the other CSA technologies, such as irrigation, fish farming, biogas digester, and inorganic fertilizers, high initial investment costs were cited as the main reason for the low adoption rates.

Some of the suggested specific actions that could improve farmers' use of the practices included timely availability of weather information in a language they can understand. As indicated in Table 1, the majority of the farmers interviewed have no formal education or only attained primary education. Other suggestions included cheaper and easier to establish water harvesting techniques and soil conservation measures that are suitable to their soil type and the steep landscape of Lushoto, access to initial financing to purchase inorganic fertilizers, irrigation and biogas generation equipment, and training on the establishment of terraces on steep slopes. Motivation to act, articulation of demand for support, and dependency were also important dimensions of adaptive capacity building that emerged as an aspect of the FotF approach. Seeing and hearing positive explanations of the weather stations helped create demand for the equipment amongst participants and training on how to collect climate data.

\subsection{Awareness and Use of CSA Technologies}

Apart from the specific CSA technologies farmers were exposed to during the learning journey, we also examined the overall level of awareness and use of other CSA technologies among farmers in Lushoto. The farmers reported over 20 different CSA practices that they were aware of either used on their own or in different combinations within the farm. Most of the CSA practices reported by the farmers are consistent with the FAO definition of CSA (see Section 1) [52]. Table 4 summarizes the various CSA practices used for crop and livestock production, soil and water conservation, energy saving and other income generating technologies. The majority of the farmers interviewed were aware of the different CSA practices. More than three-quarters of the households were aware of improved or multiple stress tolerant crop varieties such as Lyamungo90 bean varieties, composting, inorganic fertilizers, early planting, cut and carry livestock feeding, agroforestry, and local tolerant varieties. More than half of the households were aware of intercropping, minimum tillage, mulching, crop rotation, scientific and traditional weather forecasting, non-burning, terraces and contour planting, and improved fodder. Fewer households (less that 45 percent) were aware of biogas, Matengo pits, SACCOs, and strip cropping CSA practices, the four technologies and practices that farmers who participated in the FotF were exposed to during the learning journey (see previous section).

The findings indicate that there was a high correlation between awareness and use of the CSA technologies. Of the CSA technologies that farmers were aware of-improved crop varieties, composting, cut and carry feeding, use of inorganic fertilizers, agroforestry, and early crop planting-were the most commonly used by the farmers (Table 4). Biogas for efficient energy use and improved cooking stoves reduces GHG emissions. Waste from animals used in biogas equipment for anaerobic digestion can provide solutions to energy supply for cooking and lighting in Lushoto, and the byproduct as agricultural fertilizer [53-55]. Despite biogas technology utilizing energy sources without depleting natural resources and are as environmentally benign as possible, investment costs for farmers in Lushoto are very high, thus limiting their adoption. Matengo pits for water conservation and involvement in SACCOs were the other two practices least used by the farmers. 
Table 4. Awareness and use of CSA technologies and practices in Lushoto.

\begin{tabular}{cccc}
\hline $\begin{array}{c}\text { CSA Technologies and } \\
\text { Practices }\end{array}$ & $\begin{array}{c}\text { Percent of Households } \\
\text { Aware of the CSA } \\
\text { Technology and Practice }\end{array}$ & $\begin{array}{c}\text { Percent of Households } \\
\text { Aware and Using the CSA } \\
\text { Technology and Practice }\end{array}$ & $\begin{array}{c}\text { Pearson Correlation } \\
\text { Coefficient }\end{array}$ \\
\hline Improved crop varieties & 97.5 & 95.1 & $0.69^{* *}$ \\
Composting & 88.9 & 87.7 & $0.94^{* *}$ \\
Cut and carry feeding & 87.7 & 80.3 & $0.76^{* *}$ \\
Chemical fertilizers & 86.4 & 81.5 & $0.83^{* *}$ \\
Agroforestry & 85.2 & 85.2 & $1.00^{* *}$ \\
Early planting & 80.3 & 64.2 & $0.66^{* *}$ \\
Local crop varieties & 76.5 & 42.0 & $0.47^{* *}$ \\
Intercropping & 74.1 & 67.9 & $0.86^{* *}$ \\
Minimal tillage & 71.60 & 70.7 & $0.97^{* *}$ \\
Mulching & 69.1 & 66.7 & $0.94^{* *}$ \\
Scientific weather forecasting & 67.9 & 67.9 & $1.00^{* *}$ \\
Crop rotation & 66.7 & 65.4 & $0.97^{* *}$ \\
Traditional weather forecasts & 66.7 & 65.4 & $0.97^{* *}$ \\
Non-burning & 65.4 & 63.0 & $0.95^{* *}$ \\
Terraces, contour planting & 60.5 & 37.0 & $0.62^{* *}$ \\
Improved fodder & 58.0 & 53.1 & $0.91^{* *}$ \\
Irrigation technologies & 40.7 & 16.1 & $0.53^{* *}$ \\
SACCOS & 40.7 & 3.7 & $0.24^{*}$ \\
Efficient stoves & 38.3 & 27.2 & $0.77^{* *}$ \\
Organic pest control & 38.3 & 35.8 & $0.95^{* *}$ \\
Strip cropping & 28.4 & 23.5 & $0.88^{* *}$ \\
Biogas, biodigester & 18.5 & 1.2 & $0.24^{*}$ \\
Matengo pits & 16.1 & 6.2 & $0.59^{* *}$ \\
\hline
\end{tabular}

${ }^{1}$ These are locally available varieties that are preferred by farmers and least affected by extreme weather conditions and pest and diseases; ${ }^{*}$ Correlation is significant at the 0.05 level (two-tailed); ${ }^{* *}$ Correlation is significant at the 0.01 level (two-tailed).

While most farmers are aware of many CSA practices and innovations, only a small number of the farmers are adopting the practices. Figure 4 shows the CSA practices with the highest discrepancies between awareness and use (i.e., practices farmers are aware of, yet very few use them on their farms). Most farmers indicated their willingness to use CSA practices, but are constrained by several factors including cultural practices, such as tenure and ownership rights, labor requirements, high investment costs, and lack of skills and knowledge on how to use the practices. Irrigation and SACCOs, for example, require high initial investments. Table 4 shows that these two practices had the largest discrepancies between awareness and use. Studies have shown that belonging to a rural social or marketing group enhances social and financial capital allowing trust, idea, and information exchange [56,57]. Thus, membership to a group (e.g., a SACCO) can increase the uptake of a CSA practice. However, SACCO membership will require subscription fee that most farmers in Lushoto cannot afford, even if they would like to belong to the SACCO.

On-farm diversification through different farming enterprises such as different varieties of crops, different types of livestock (including bee-keeping, poultry) and fish farming, are important risk management strategies and can cushion farmers and their families during bad seasons or years. In addition, farmers can engage in non-farming activities such as value addition enterprises. Livelihood diversification, on-farm and off-farm, is a key risk management strategy and can also increase farmers adaptive capacity [58-60]. 


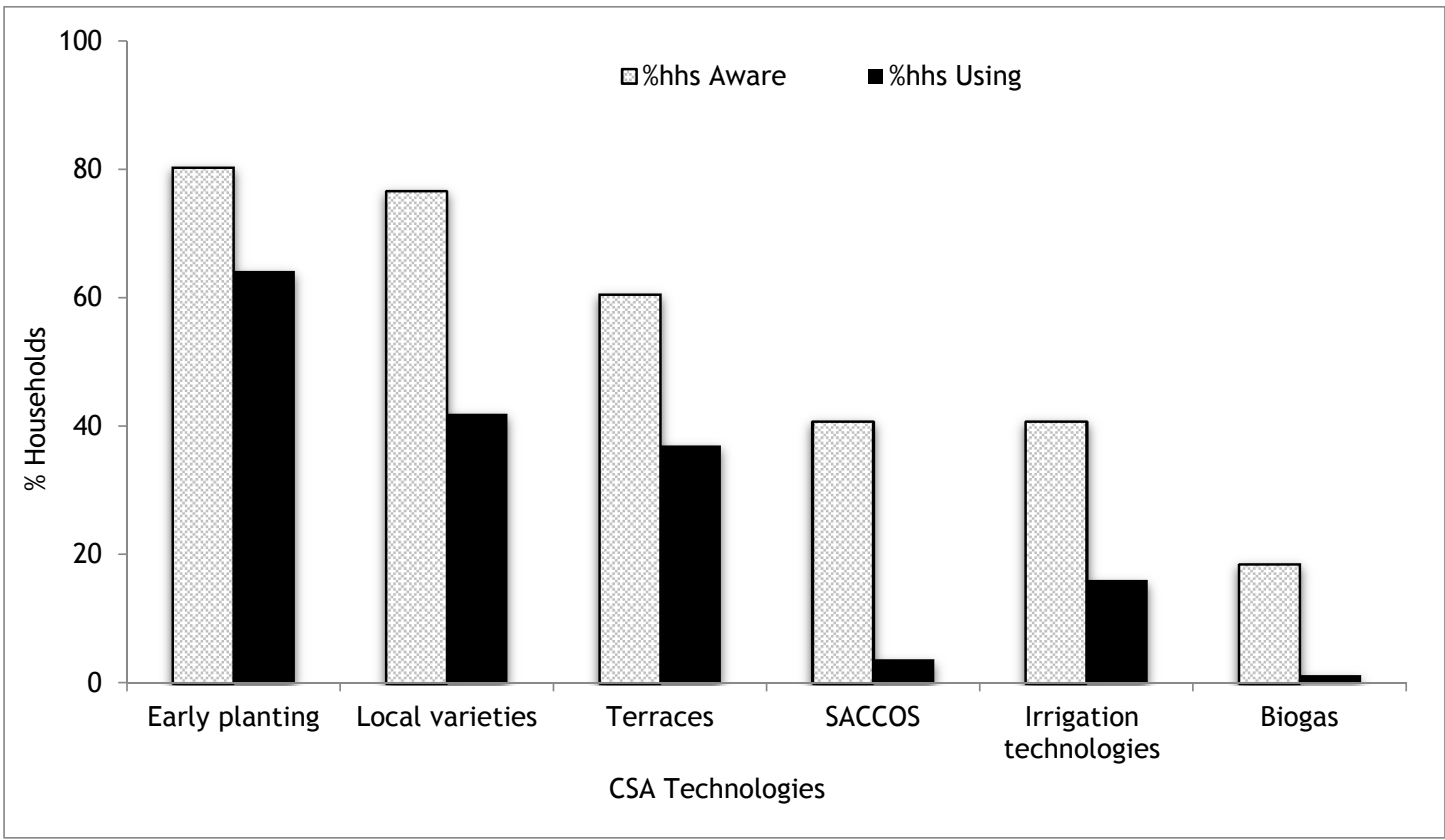

Figure 4. CSA practices with the largest discrepancies between awareness and use of practice in Lushoto.

\subsection{Gender Differentiated Preferences and Use of CSA Technologies and Practices}

In this section, we examine the most important CSA technologies and practices used in Lushoto, and if they differ by gender. Households were asked to rank (of equal weighting) the CSA practices based on the benefits and potential to enhance their capacity to adapt to climate change (Table 5). The three most commonly cited CSA practices for women were intercropping, strip cropping, and use of inorganic fertilizers. For men, the practices were minimal tillage, cut and carry feeding for livestock, and improved crop varieties. There were no significant gender differences in preference and use of CSA practices, except for intercropping, where 72 percent of women cited it as important compared to 28 percent of men, and use of strip cropping, in which 46 percent of women found it important compared to 54 percent of men (Table 5).

Table 5. Gender differentiated CSA practices cited as the most important for adapting to climate change by farmers.

\begin{tabular}{cccc}
\hline Most Important CSA Practices & \multicolumn{3}{c}{ Percent of Households } \\
\hline & Total $(\boldsymbol{n = 8 1 )}$ & Male & Female \\
\hline Improved crop varieties & 51.9 & 73.8 & 26.2 \\
Composting & 44.4 & 72.2 & 27.8 \\
Chemical fertilizers & 37.0 & 56.7 & 43.3 \\
Agro forestry & 28.4 & 73.9 & 26.1 \\
Intercropping & 22.2 & 27.8 & 72.2 \\
Cut and carry feeding & 21.0 & 76.5 & 23.5 \\
Strip cropping & 13.6 & 54.6 & 45.5 \\
Minimal tillage & 12.4 & 80.0 & 20.0 \\
Early planting & 9.9 & 62.5 & 37.5 \\
\hline
\end{tabular}

On-farm diversification through various CSA practices is crucial in climate-risk management, especially amongst the smallholder farmers of Lushoto. Already, Lushoto farmers are integrating several CSA practices on their farms to minimize crop and livestock losses during extreme weather 
events. On average, men- and women-headed households integrate 10 and five CSA practices respectively. Even though this is consistent with findings from previous studies that report increasing diversified smallholder farms in East Africa. It is important to point out that women-headed households have fewer CSA practices on farms than male-headed. Reasons for the difference included (a) women have limited access to and use of assets such as land and hence unable to adopt long-term practices such as agroforestry; (b) women pursue different livelihood portfolios and (c) men are more risk takers in that they have access to assets including credit and extension services.

It is interesting that women did not mention efficient energy stoves as one of their top three CSA practices. The energy stove practice that farmers learned during the climate journey leads to reduction in the amount of fuelwood used, and it would significantly improve indoor air quality, improving the health of women [61]. The traditional methods of cooking that women use, including open air fire, causes deaths from chronic obstructive pulmonary disease, pneumonia in children under the age of five, lung cancer, and other non-communicable diseases such as heart disease, stroke, and cataract [61,62]. Moreover, energy efficient biomass stoves have been shown to reduce fuel consumption within households by up to 40 percent [63]. This provides a triple win strategy for income, health, and mitigation and yet the women farmers in Lushoto do not mention it as important. This calls for increased awareness in women on energy-efficient stoves.

\section{CSA Information Sources and Dissemination Pathways}

In this section we explore how farmers in Lushoto access information about CSA and other services that support CSA, such as credit that can enable farmers to build resilience. We also look at the CSA dissemination pathways. Households in Lushoto access weather and agricultural information from various sources. The majority of the households rely heavily on radio, friends, and relatives, as well as their own observations for information, particularly weather forecasting information, both in the short and long run $[64,65]$. The government is a key source of information on pest and disease outbreak projections, and traditional sources, or indigenous knowledge, are still relied upon by some, particularly with respect to forecasts of extreme events and the onset of the rains [65]. Newspapers, local groups, NGO's, village meetings, and televisions are not common sources of weather or agricultural information in Lushoto.

Most of the farmers (over 98 percent) reported that they receive agricultural information orally. This is applicable for crop and livestock production as well as tree planting activities. For crop production, farmers need information at the time of planting, use of proper seed, proper seed spacing, crop rotation, use of traditional and scientific weather information, and appropriate land preparation practices, such as no-tillage. For livestock production, farmers would like information on proper feeds and fodder production, management, vaccinations, deworming, reducing the number of herd, and zero-grazing system. Government extension services are the main source of oral information (75 percent). Other sources include a farmer's own experience (26 percent), traditional knowledge (11 percent) researchers (seven percent), neighbors (six percent), and agri-service providers and seed companies. Farmers reported that the information they receive can enable them to start preparing for the changing climate up to 20 years into the future. This was reported by more than 99 percent of the respondents. Improving agricultural productivity was the major motivation for seeking and using information and technologies on crop husbandry, new varieties and techniques, and improvement of soil fertility.

More than half (55 percent) of the respondents indicated that the men make decisions on how information is used within the household, while 23 percent said that it is the woman, Thirteen percent indicated that both women and men are involved in the decision making process. In terms of use of new technologies, 45 percent of respondents reported that both men and women are involved. It is, therefore, critical to ensure that information is shared within the entire household, including both women and men. The information also needs to be packaged to suit the different audiences. 
The farmers and the AIS who participated in the FotF learning journey were expected to widely share what they had learnt with other farmers. During the journey, participating farmers used video recording (flip cameras) to document the learning process. Upon return, the video clips were edited and shared with other farmers in Yamba and Mbuzii who did not participate in the learning visit. Farmers who participated in the learning journey shared information on tree planting, SACCOS, land conservation, bee-keeping, and Matengo pits, mainly with family members ( 28 percent), members of the same village (32 percent), members of the neighboring village (30 percent), and members of other far-away villages (10 percent).

Farmers were asked about the practical CSA information dissemination pathways that can be used to reach the majority of farmers, especially women and other disadvantaged groups. Understanding dissemination pathways involves considering horizontal (peer-to-peer through face to face interactions, word of mouth, farmer meetings) and vertical (upwards and downwards amongst farmers, extension providers, researcher to farmer, and use of radios or cellphones) pathways [66]. Decisions on which dissemination pathway to use depend on farmers' skills, needs, and resources to receive and use the information $[67,68]$. We used FGDs and cobweb mapping exercises to enable farmers to visually map the different CSA dissemination pathways. The FGDs generated a simple checklist of critical stakeholders that are considered important sources of information. Afterwards, cobweb networks diagrams were drawn by FGDs to help in visualizing the relative importance of sources of information on CSA practices (Figure 5). A higher point indicates the most preferred as well as trusted source of CSA information.

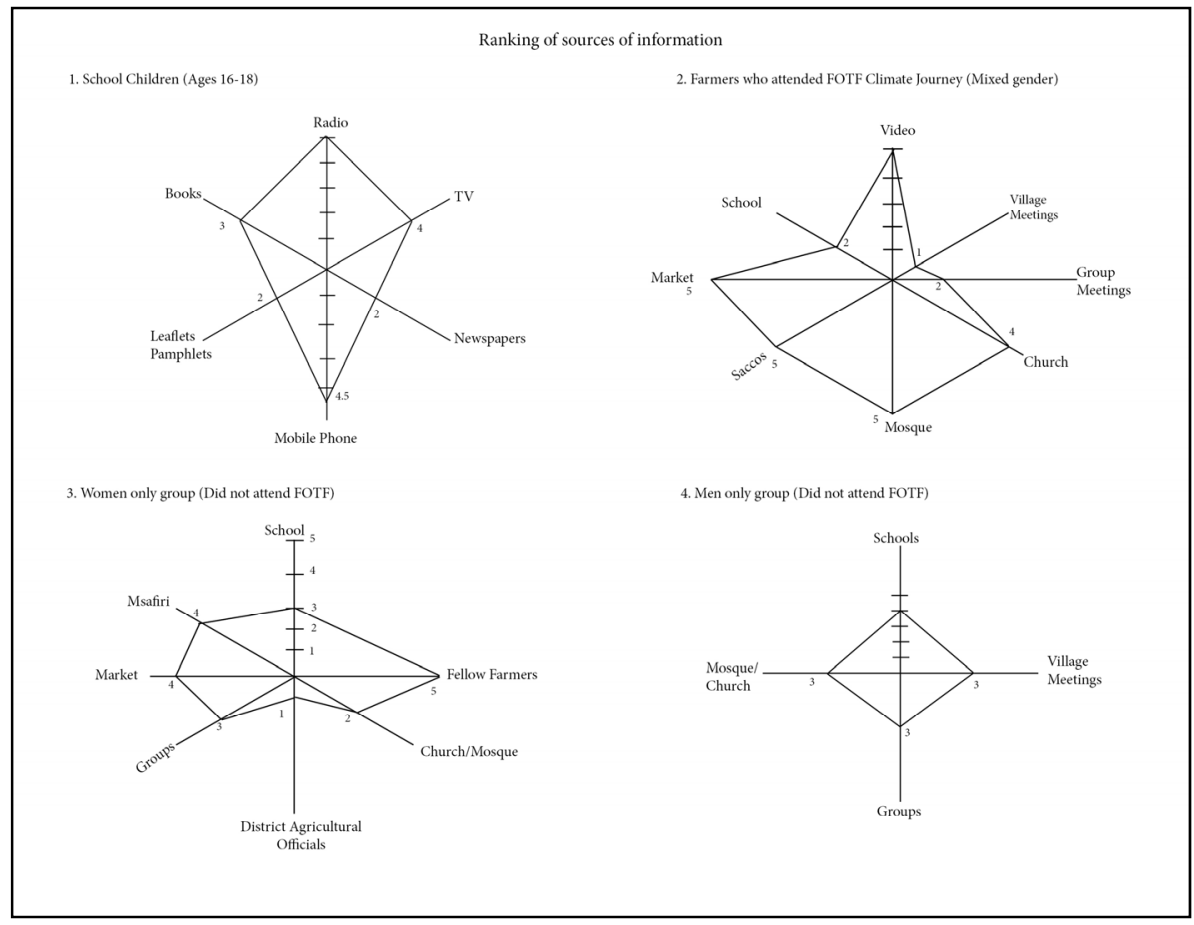

Figure 5. Cobweb diagram showing ranking on importance of sources of information for CSA practices and technologies.

The cobweb mapping revealed that informal and formal institutions, such as village and religious groups, are the most common institutions for accessing information. They provide less formalized, but effective, methods of communicating information within Lushoto, as well as spreading the CSA practices to other neighboring villages. This was noted in the FGDs for FotF farmers and women only. School children, who are potential future farmers, preferred the latest information and communication technologies, especially mobile phones and television. This is important for scaling up CSA practices 
among the youth because an effective dissemination pathway depends not only on how successful the pathway influences farmers' decision to adopt, but the number of people receiving the information. Through mobile phones and television, scaling up CSA practices can reach more farmers and future farmers as well.

Despite the increased interactions, dissemination and sharing of information about CSA practices among farmers, access to new CSA practices will be hampered by persistent poor linkages between farmers and agro-advisory service providers. Farmers discussions reveal the information flow and linkages between extension officers and farmers is still weak and there is a need to improve access to information for farmers, including exploring others ways that farmers can easily access information on CSA practices and technologies. The combination of a changing climate and declining soil fertility is making farmers not only demand weather and agro-advisory services, but the investment of time and money to acquire the services.

\section{Farmers' Perceptions of the Learning Journey}

Using FGDs, farmers (those who participated in the learning journey and those who did not) and the AIS were asked their perceptions of the learning journey in order to help researchers improve, modify, and make any other adjustments for similar visits in the future. This was done through the FGDs and the surveys. Farmer's perceptions of the FotF journey were similar to those reported from the post visit analyses by [69]. For most of the farmers, the climate journey was a useful tool for learning different CSA practices and interacting with other farmers and AIS stakeholders. The timing of the FotF learning journey was excellent, as the farmers learned from other farmers, while crops were growing. Including the AIS actors in the learning journey enhanced the farmers learning experiences, as they provided explanations and opportunities for discussions about CSA technologies for which the farmers had limited knowledge and understanding. Presence of AIS actors facilitated learning between them and the farmers [69], as well as information sharing with other farmers who did not participate in the learning journey.

Specific areas where improvements are needed included trip duration-where the farmers observed that they did not get enough time to absorb all the knowledge that they were learning, more representation from women and youth, and increasing the total number of farmers participating to be proportional to the population of a given target area. While the selection criteria for participation in the learning journey was based on gender balance, spread across different ages, 50 percent of farmers surveyed in CCAFS survey, and farmers demonstrating capabilities in filming [69], only two out of the 15 participants were women. Of the five AIS actors who participated, only one was a woman (Community Development Officer). Low participation of women farmers is largely attributed to the cultural practices and barriers within the communities, where men are uncomfortable with their wives spending nights out of the home. Rural women, who are agrarian based and provide most of the labor for agricultural production, will be highly vulnerable to the impacts of climate change and, therefore, more women need to participate in learning initiatives [70,71].

The diversity of AIS actors from government and private agricultural entrepreneurs draw from a range of sectors including agriculture, commerce/business, tourism, and social development shows that the impacts of climate change is felt across all sectors of Tanzania's economy. Indeed, the impacts of climate change at the farm level can ripple through the business and entrepreneurial community because if agriculture fails, farmers will not have income that can sustain business. For the AIS actors, the learning journey increased their understanding of the impacts of climate change and how it affects communities across Tanzania.

As a community development officer reported:

"Throughout the journey, I observed farmers soaking in agricultural information from other farmers along the way. I too learned how a changing climate is affecting families and their livelihoods. The experience from the journey has improved my understanding of climate change and the various climate-smart practices that farmers can adopt both in Lushoto and other villages of Tanzania". 
Other AIS actors shared similar sentiments. An agricultural input trader store commented that:

"I have to keep up to date with weather from radios and newspapers, especially the onset of rains and how much rains we expect each season. This will enable me to stock the right crop seeds for farmers. For example, maize seed that can grow in a short period of time is going to be appropriate for farmers when we have less rain. I will need to also keep in contact with the extension officer who can provide the latest information on climate-smart practices".

Apart from the agricultural input trader, the rest of the AIS actors have not influenced adoption of CSA practices amongst Lushoto farmers, including those who participated in the learning trip. Results from FGDs show that there has been no interaction between the farmers and the other AIS actors after the journey. The District Agricultural and Livestock Development Officer and the District Extension Officer, both of whom are in direct contact with the farmers, have not shared what they learned with the farmers. This shows that the information flow and linkages between extension officers and farmers is still weak and there is need to improve access to information for farmers, including exploring others ways that farmers can easily access information on CSA practices and technologies.

\section{Conclusions}

East African small-holder, subsistence farming is facing unprecedented stress when attempting to increase productivity with the glaring realities of climate variability and change. Failure to be prepared for the effects of climate change can results in hunger, malnutrition, a breakdown in social structures, increased insecurity, and poverty among others. Therefore, farmers, especially the youth who are expected to be future farmers, need to be prepared not only with CSA technologies, but climate risk management strategies such as timely meteorological information, crop and livestock insurance, credit, and institutions, such as farmers' organizations. Furthermore, due to the nature of the landscape in Lushoto Climate-Smart Village (CSV), the subsistence farmers must be anticipatory with long-term adaptive strategies that are inclusive and proactive at households and landscape level [4].

Information and communication is needed by farmer on risks and risk management. Organizations providing agro-advisory information should be involved in investigating and disseminating information on risks from weather variability that can cause yield and price volatility. Access to climate adaptation, mitigation, and risk management information is key to taking the necessary risk reducing measures. For example, farmers can minimize their risks and increase yields by adjusting planting dates and planting areas (hillside vs. valley bottom have differential soil moisture content) in response to seasonal forecasts. Government, private sector, non-governmental organizations and community based organizations that are agriculturally related and operating in Lushoto village can facilitate good "start-up" conditions each season by providing a package of risk management tools, including climate information and agronomic husbandry practices and training. Giving farmers the appropriate information about their circumstances/environment will make them well-placed to assess risks, identify vulnerabilities, and use appropriate CSA practices.

The use of the climate-analogue tool, combined with the FotF approach, is a useful adaptation tool because it enables farmers to know what their future climate will be like so they can start preparing for it. Adding a learning journey where the farmers are able to visit areas already experiencing their future climate provided an opportunity to learn from other farmers and see first-hand their plausible future climatic conditions, allowing farmers to strengthen their adaptive capabilities. The learning journey also enables farmers to identify new sustainable and climate-resilient agricultural practices, to be inspired and be motivated to change. The farmers are able understand their environment better by comparing and contrasting it to other environments (farming practices, cultural, and social norms). Finally, use of FotF approach to enhance farmer-to-farmer adaptation learning should be supported by follow-up trainings, especially for those technologies and practices where farmers have very limited knowledge. Continuous learning and sharing of CSA practices, climate, and agro-advisory information should become an essential tool for farmers, financial institutions, and agro-advisory 
service providers. This will inevitably enhance farmer's adaptive capacity while improving their knowledge and changing their attitudes towards climate-smart farming.

Acknowledgments: We wish to express our sincere appreciation to Lushoto farmers, particularly from Mbuzii, Yamba, Gare, and Kwang'wenda villages, for participating in the study. We also wish to acknowledge George Sayula and Gladness Martin from Selian Agricultural Research Institute (SARI), Juma Wickama from Agricultural Research Institute (ARI) Mlingano, Tumaini Gwatalile-Lushoto community development officer and the district agricultural extension officer Elizabeth Musoka for supporting the fieldwork. This work was implemented as part of the CGIAR Research Program on Climate Change, Agriculture and Food Security (CCAFS), which is carried out with support from CGIAR Fund Donors and through bilateral funding agreements. For details please visit https:/ / ccafs.cgiar.org/donors.

Author Contributions: Mary Nyasimi designed and carried out the research and led writing of the manuscript. Philip Kimeli contributed to the design of the survey tools and led household sampling, field data collection, data analysis and writing. George Sayula contributed to the design of study, coordinated and facilitated the field data collection. Maren Radeny provided the overall technical guidance for the analysis of the data and writing, contributing significantly to the overall structure and flow of the manuscript. James Kinyangi contributed to the study design, reviewing the objectives and survey methods and reviewed the manuscript to improve the coherence of the content. Catherine Mungai participated in developing the concept and write up.

Conflicts of Interest: The authors declare no conflict of interest. All authors read and approved the final manuscript.

\section{References}

1. Jayne, T.S.; Chamberlin, J.; Headey, D.D. Land pressures, the evolution of farming systems, and development strategies in Africa: A synthesis. Food Policy 2014, 48, 1-17. [CrossRef]

2. Addae-Korankye, A. Causes of Poverty in Africa: A Review of Literature. Am. Int. J. Soc. Sci. 2014, 3, 147-153.

3. Sanchez, P.A.; Swaminathan, M.S. Hunger in Africa: The link between unhealthy people and unhealthy soil. Lancet 2005, 265, 442-444. [CrossRef]

4. Diale, N.R. Socio-economic indicators influencing the adoption of hybrid Sorghum: The Sekhukhune District perspective. S. Afr. J. Agric. Ext. 2011, 39, 75-85.

5. Okwi, P.O.; Ndeng'e, G.; Kristjanson, P.; Arunga, M.; Notenbaert, A.; Omolo, A.; Henninger, N.; Benson, T.; Kariuki, P.; Owuor, J. Spatial determinants of poverty in rural Kenya. Proc. Acad. Natl. Sci. USA 2007, 104, 16769-16774. [CrossRef] [PubMed]

6. Williamson, T.; Hesseln, H.; Johnston, M. Adaptive capacity deficits and adaptive capacity of economic systems in climate change vulnerability assessment. For. Policy Econ. 2010. [CrossRef]

7. Berkes, F.; Colding, J.; Folke, C. Navigating Social-Ecological Systems: Building Resilience for Complexity and Change; Cambridge University Press: Cambridge, UK, 2003.

8. Intergovernmental Panel on Climate Change (IPCC); Niang, I.; Ruppel, O.C.; Abdrabo, M.A.; Essel, A.; Lennard, C.; Padgham, J.; Urquhart, P. Climate Change 2014; Working Group II AR5: Impacts, Adaptation, and Vulnerability: Part B: Regional Aspects. Contribution of Working Group II to the Fifth Assessment Report of the Intergovernmental Panel on Climate Change; Barros, V.R., Field, C.B., Dokken, D.J., Mastrandrea, M.D., Mach, K.J., Bilir, T.E., Chatterjee, M., Ebi, K.L., Estrada, Y.O., Genova, R.C., et al., Eds.; Cambridge University Press: Cambridge, UK; New York, NY, USA, 2014; pp. 1199-1265.

9. Seneviratne, S.I.; Nicholls, N.; Easterling, D.; Goodess, C.M.; Kanae, S.; Kossin, J.; Luo, Y.; Marengo, J.; McInnes, K.; Rahimi, M.; et al. Changes in climate extremes and their impacts on the natural physical environment. In Managing the Risks of Extreme Events and Disasters to Advance Climate Change Adaptation. A Special Report of Working Groups I and II of the Intergovernmental Panel on Climate Change; Field, C.B., Barros, V., Stocker, T.F., Qin, D., Dokken, D.J., Ebi, K.L., Mastrandrea, M.D., Mach, K.J., Plattner, G.-K., Allen, S.K., et al., Eds.; Cambridge University Press: Cambridge, UK; New York, NY, USA, 2012; pp. 109-230.

10. Intergovernmental Panel on Climate Change (IPCC). Climate Change 2001: Impacts, Adaptation, and Vulnerability: Contribution of Working Group II to the Third Assessment Report of the Intergovernmental Panel on Climate Change; Cambridge University Press: Cambridge, UK, 2001.

11. Biggs, S.D. Agricultural Technology Generation and Diffusion: Lessons for Research Policy; Overseas Development Institute: London, UK; ODI Agricultural Administration Unit: London, UK, 1986. 
12. Food and Agriculture Organization (FAO). Food Security and Agricultural Mitigation in Developing Countries: Option for Capturing Synergies; Food and Agriculture Organization: Rome, Italy, 2009.

13. Lyamchai, C.; Yanda, P.; Sayula, G.; Kristjanson, P. Summary of Baseline Household Survey Results: Lushoto, Tanzania; CGIAR Research Program on Climate Change, Agriculture and Food Security (CCAFS): Copenhagen, Denmark, 2011. Available online: www.ccafs.cgiar.org (accessed on 20 August 2016).

14. Williams, J.W.; Jackson, S.T.; Kutzbach, J.E. Projected distributions of novel and disappearing climates by 2100 AD. Proc. Acad. Natl. Sci. USA 2007, 104, 5738-5742. [CrossRef] [PubMed]

15. Ramírez-Villegas, J.; Lau, C.; Köhler, A.-K.; Signer, J.; Jarvis, A.; Arnell, N.; Osborne, T.; Hooker, J. Climate Analogues: Finding Tomorrow's Agriculture Today; Working Paper No. 12; CGIAR Research Program on Climate Change, Agriculture and Food Security (CCAFS): Cali, Colombia, 2011. Available online: http: / / www.ccafs.cgiar.org/resources/working-papers (accessed on 4 July 2013).

16. Nordin, S.M.; Noor, S.M.; Md Saad, M.S. Innovation Diffusion of New Technologies in the Malaysian Paddy Fertilizer Industry. Pocedia Behav. Sci. 2014, 109, 768-778. [CrossRef]

17. Rao, E.J.O.; Qaim, M. Supermarkets, Farm Household Income, and Poverty: Insights from Kenya. World Dev. 2010, 39, 784-796. [CrossRef]

18. Phiri, D.; Franzel, S.; Mafongoya, P.; Jere, I.; Katanga, R.; Phiri, S. Who is using the new technology? The association of wealth status and gender with the planting of improved tree fallows in Eastern Province, Zambia. Agric. Syst. 2004, 79, 131-144. [CrossRef]

19. Bandiera, O.; Rasul, M. Social Networks and Technology Adoption in Northern Mozambique. Econ. J. 2006, 116, 862-902. [CrossRef]

20. Ariyo, O.C.; Ariyo, M.O.; Okelola, O.E.; Aasa, O.S.; Awotide, O.G.; Aaron, A.J.; Oni, O.B. Assessment of the Role of Mass Media in the Dissemination of Agricultural Technologies among Farmers in Kaduna North Local Government Area of Kaduna State, Nigeria. J. Biol. Agric. Healthc. 2013, 3, 19-28.

21. Irfan, M.; Muhammad, S.; Khan, G.A.; Muhammad, A. Role of Mass Media in the Dissemination of Agricultural Technologies among Farmers. Int. J. Agric. Biol. 2006, 8, 417-419.

22. Jarvis, A.; Ramirez-Villegas, J.; Nelson, V.; Lamboll, R.; Nathaniels, N.; Radeny, M.; Mungai, C.; Bonilla-Findji, O.; Arango, D.; Peterson, C. Farms of the Future: An Innovative Approach for Strengthening Adaptive Capacity; Climate Change, Agriculture and Food Security (CCAFS): Cophengan, Denmark, 2012.

23. Faysse, N. Troubles on the way: An analysis of the challenges faced by multi-stakeholder platforms. Nat. Resour. Forum 2006, 30, 219-229. [CrossRef]

24. Schut, M.; Klerkx, L.; Rodenburg, J.; Kayeke, J.; Hinnou, L.C.; Raboanarielina, C.M.; Adegbola, P.Y.; van Ast, A.; Bastiaans, L. RAAIS: Rapid Appraisal of Agricultural Innovation Systems (Part I). A diagnostic tool for integrated analysis of complex problems and innovation capacity. Agric. Syst. 2015, 132, 1-11. [CrossRef]

25. Giller, K.E.; Tittonell, P.; Rufino, M.C.; van Wijk, M.T.; Zingore, S.; Mapfumo, P.; Adjei-Nsiah, S.; Herrero, M.; Chikowo, R.; Corbeels, M.; et al. Communicating complexity: Integrated assessment of trade-offs concerning soil fertility management within African farming systems to support innovation and development. Agric. Syst. 2011, 104, 191-203. [CrossRef]

26. McNie, E.C. Reconciling the supply of scientific information with user demands: An analysis of the problem and review of the literature. Environ. Sci. Policy 2007, 10, 17-38. [CrossRef]

27. Nelson, V.; Lamboll, R.; Nathaniels, N. Farms of the Future, Tanzania; CCAFS Technical Report; CCAFS: Copenhagen, Denmark, 2012.

28. Gifford, R.; Kormos, C.; McIntyre, A. Behavioral dimensions of climate change: Drivers, responses, barriers, and interventions. WIREs Clim. Chang. 2011, 2, 801-827. [CrossRef]

29. Productivity Commission. Barriers to Effective Climate Change Adaptation LB2 Collins Street East Melbourne 8003 Victoria; Insurance Australia Group: Sidney, Australia, 2011.

30. Tanzania Meteorological Agency (TMA). Rainfall and Temperature Data for Tabora Region for the Years 1972-2008; TMA: Dar es salaam, Tanzania, 2009.

31. Tanzania Meteorological Agency (TMA). Rainfall and Temperature Data for Tumbi Station for the Years 1972-2008; TMA: Tabora, Tanzania, 2009.

32. Sattar, R.A.; Wang, S.; Muqadas, M.; Ashraf, M.F.; Tahir, M.N. Qualitative and quantitative approaches to study adoption of sustainable agricultural practices: A research-note on mixed method approach. Int. J. Agric. Ext. Rural Dev. 2017, 5, 539-544. 
33. Johnson, R.B.; Onwuegbuzie, A.J. Mixed Methods Research: A Research Paradigm Whose Time Has Come. Educ. Res. 2004, 33, 14-26. [CrossRef]

34. Creswell, J.W. Research Design. Qualitative, Quantitative, and Mixed Methods Approaches, 4th ed.; Sage: Thousand Oaks, CA, USA, 2014.

35. O'Cathain, A. Assessing the quality of mixed methods research: Towards a comprehensive framework. In SAGE Handbook of Mixed Methods in Social and Behavioral Research, 2nd ed.; Tashakkori, A., Teddlie, C., Eds.; Sage: Thousand Oaks, CA, USA, 2010; pp. 531-558.

36. Food and Agriculture Organization (FAO). African youth in Agriculture, natural resources and rural development. Nat. Faune 2013, 28, 1-98.

37. Food and Agriculture Organization (FAO); International Fund for Agricultural Development (IFAD); International Labour Organization (ILO). Agricultural Value Chain Development: Threat or Opportunity for Women's Employment? Available online: http://www.fao.org/docrep/013/i2008e/i2008e04.pdf (accessed on 12 May 2017).

38. Peterson, C.A.; Nyasimi, M.; Kimeli, P. Local-Level Appraisal of Benefits and Barriers Affecting Adoption of Climate-Smart Agricultural Practices: Lushoto, Tanzania; CGIAR Research Program on Climate Change, Agriculture and Food Security (CCAFS): Copenhagen, Denmark, 2014.

39. Sanga, C.; Kalungwizi, J.; Msuya, C.P. Building an agricultural extension services system supported by ICTs in Tanzania: Progress made, Challenges remain. Int. J. Educ. Dev. Using Inf. Commun. Technol. 2013, 9, 80-99.

40. Waithaka, M.M.; Thornton, P.K.; Shepherd, K.D.; Ndiwa, N.N. Factors affecting the use of fertilizers and manure by smallholders: The case of Vihiga, western Kenya. Nutr. Cycl. Agroecosyst. 2007, 78, 211-224. [CrossRef]

41. Mahoo, H.; Mbungu, W.; Yonah, I.; Recha, J.; Radeny, M.; Kimeli, P.; Kinyangi, J. Integrating Indigenous Knowledge with Scientific Seasonal Forecasts for Climate Risk Management in Lushoto District in Tanzania; CCAFS Working Paper No. 103; CGIAR Research Program on Climate Change, Agriculture and Food Security (CCAFS): Copenhagen, Denmark, 2015. Available online: www.ccafs.cgiar.org (accessed on 8 May 2014).

42. Wanyama, F.O.; Develtere, P.; Pollet, I. Encountering the Evidence: Cooperatives and Poverty Reduction in Africa; Working Paper on Social and Cooperative Entrepreneurship WP-SCE-08-02; Social Science Research Network (SSRN): New York, NY, USA, 2008.

43. World Bank. Aide Memoire, Tanzania: Second Financial Institutions Development Project and Rural and Microfinancial Services Project; Thompson, A., Ouattara, K., Byakuma, J., Eds.; World Bank: Washington, DC, USA, 2002.

44. Alpert, E.; Smale, M.; Hausrer, K. Investing in Small Farmers Pays: Rethinking How to Invest in Agriculture; Oxfam International: Oxford, UK, 2009.

45. Food and Agriculture Organization (FAO). The State of Food and Agriculture: Women in Agriculture, Closing the Gender Gap for Development; FAO: Rome, Italy, 2011.

46. Food and Agriculture Organization (FAO). Gender Dimensions of Agricultural and Rural Employment: Differentiated Pathways out of Poverty; Status, Trends and Gaps; FAO: Rome, Italy, 2010.

47. Conway, D.; Lisa, E.; Schipper, F. Adaptation to climate change in Africa: Challenges and opportunities identified from Ethiopia. Glob. Environ. Chang. 2010, 21, 227-237. [CrossRef]

48. Lu, X. Applying Climate Information for Adaptation Decision-Making: A Guidance and Resource Document; National Communications Support Programme (NCSP) UNDP-UNEP-GEF: New York, NY, USA, 2009.

49. United Nations Development Programme (UNDP). Improving Access, Understanding and Application of Climate Data and Information; Africa Adaptation Programme: Capacity Building Experiences; Discussion Paper Series; UNDP: New York, NY, USA, 2011.

50. Meliyo, J.; Kabushemera, J.W.; Tenge, A.J. Characterization and Mapping Soils of Kwalei Subcatchment, Lushoto District; Agricultural Research Institute: Mlingano, Tanga, Tanzania, 2002.

51. Sijmons, K.; Kiplimo, J.; Förch, W.; Thornton, P.K.; Radeny, M.; Kinyangi, J. CCAFS Site Atlas—Makueni/Wote; CCAFS Site Atlas Series: Copenhagen, Denmark, 2013. Available online: http:/ / issuu.com/cgiarclimate/ docs / tanzanialushoto/1? e=4405409/4912517 (accessed on 23 February 2015).

52. Food and Agriculture Organization (FAO). Energy and Gender in Rural Sustainable Development; FAO: Rome, Italy, 2006.

53. Chand, B.; Upadhyay, B.P.; Maskey, R. Biogas Option for Mitigating and Adaptation of Climate Change. Rentech Symp. Compend. 2012, 1, 5-9. 
54. SEA \& AMATHEMBA. Smart Living Handbook. City of Cape Town: Sustainable Energy Africa and AMATHEMBA Environmental Management Consulting. 2007. Available online: https:/ / www.capetown.gov.za/en/EnvironmentalResourceManagement/Documents/Smart_Living_ Handbook_Eng_FULL\%20VERSION_4thEd_2011-05.pdf (accessed on 8 May 2014).

55. Monnet, F. An Introduction Anaerobic Digestion of Organic Wastes. 2003. Available online: http:/ / www. biogasmax.co.uk/media/introanaerobicdigestion_073323000_1011_24042007.pdf (accessed on 8 May 2014).

56. Alene, A.; Manyong, V.; Omanya, G.; Mignouna, H.; Bokanga, M.; Odhiambo, G. Smallholder market participation under transaction costs: Maize supply and fertilizer demand in Kenya. Food Policy 2008, 33, 318-328. [CrossRef]

57. Place, F.; Kariuki, G.; Wangila, J.; Kristjanson, P.; Makauki, A.; Ndubi, J. Assessing the factors underlying differences in achievements of farmer groups: Methodological issues and empirical findings from the highlands of Central Kenya. Agric. Syst. 2004, 82, 257-272. [CrossRef]

58. Canon, T. Rural livelihood diversification and adaptation to climate change. In Community-Based Adaptation to Climate Change: Emerging Lessons; Ensor, J., Berger, R., Huq, S., Eds.; Practical Action Publishing: Warwickshire, UK, 2014; p. 216.

59. Osbahr, H.; Twyman, C.; Adger, W.N.; Thomas, D.S.G. Evaluating successful livelihood adaptation to climate variability and change in southern Africa. Ecol. Soc. 2010, 15, 27. [CrossRef]

60. Hellmuth, M.E.; Moorhead, A.; Thomson, M.C.; Williams, J. Climate Risk Management in Africa: Learning from Practice; International Research Institute for Climate and Society (IRI), Columbia University: New York, NY, USA, 2007.

61. Wilkinson, P.; Smith, K.R.; Davies, M.; Adair, H.; Armstrong, B.; Barrett, M.; Bruce, N.; Haines, A.; Hamilton, I.; Oreszcyn, T.; et al. Public health benefits of strategies to reduce greenhouse-gas emissions: Household energy. Lancet 2009, 374, 1917-1929. [CrossRef]

62. Rehfuess, E. Fuel for Life: Household Energy and Health; World Health Organization: Geneva, Switzerland, 2006.

63. Smith, K.R.; Mehta, S.; Musezahl-Feuz, M. Comparative Quantification of Health Risks: Global and Regional Burden of Disease Attribution to Selected Major Risk Factors; World Health Organization: Geneva, Switzerland, 2004.

64. Van den Broeck, K.; Dercon, S. Information flows and social externalities in a Tanzanian banana growing village. J. Dev. Stud. 2011, 41, 231-252. [CrossRef] [PubMed]

65. Chengula, F.; Nyambo, B. The significance of indigenous weather forecast knowledge and practices under weather variability and climate change: A case study of smallholder farmers on the slopes of Mount Kilimanjaro. Int. J. Agric. Educ. Ext. 2016, 2, 31-43.

66. Burke, A. Communication and Development: A Practical Guide; DFID: London, UK, 1999.

67. Csótó, M. Information flow in agriculture-Through new channels for improved effectiveness. J. Agric. Inform. 2010, 1, 25-34. [CrossRef]

68. Lawrence, A. Mapping information flows. ILEIA Newsl. 1997, 13, 22-23.

69. Lamboll, V.; Nelson, V.; Nathaniels, N. Farms of the Future: Briefing 1: A Promising Approach for Building Adaptive Capacity—Lessons from Tanzania; CGIAR Research Program on Climate Change, Agriculture and Food Security (CCAFS): Copenhagen, Denmark, 2013.

70. Gwivaha, F.A. Factors That Impact Agricultural Extension Training Programs for Smallholder Women Farmers in Njombe District, Tanzania; Iowa State University: Ames, IA, USA, 2015.

71. UN Women. Facts E Figures on Gender E Climate Change. Global Gender and Climate Alliance; UN Women: New York, NY, USA, 2011.

(C) 2017 by the authors. Licensee MDPI, Basel, Switzerland. This article is an open access article distributed under the terms and conditions of the Creative Commons Attribution (CC BY) license (http://creativecommons.org/licenses/by/4.0/). 